\title{
Management Control System Style and Management Accounting Techniques Adoption
}

\section{Mayada A Youssef*}

Accounting Department, College of Business and Economics, UAE

Over the last three decades a number of innovative management accounting techniques (MATs) have been developed across a range of industries. Notable contributions include activity-based costing techniques $(\mathrm{ABC})$, strategic $\mathrm{MA}$, target costing, value chain costing and the balanced scorecard (BSC). It is argued [1] that the 'new' advanced techniques have shifted the focus of MA from a 'simple' role of cost determination and financial control to a 'sophisticated' role of creating value through improved deployment of resources. However, Tillema [2] reports that many organizations have not adopted the 'advanced' techniques. She explains that the appropriateness of using such techniques may depend on the circumstances in which these techniques are being used.

Studies of MATs were implemented in a number of western countries. Examples include studies from the UK [3], USA [4], Australia [5], New Zealand [6] and Finland [7]. Other studies were implemented in eastern countries such as Saudi Arabia [8], Singapore, Malaysia, China and India [9]. Moreover, some researchers have been interested in comparing MATs between countries. Examples include a study by Luther and Longden [10] who compared MATs between South Africa and the UK and a study by Wijewardena and Zoysa [11] comparing MATs in Australia and Japan. The common findings from these surveys are that traditional MATs are still popular even outweighing advanced techniques in claimed benefits. An exception to these studies, Azhar and Abdul Rahman [12] results indicate that Malaysian service organizations perceive advanced MATs (AMATs) to be more useful than traditional MATs. Drivers of adopting or changing traditional MATs are also investigated in the literature. Shields [13] argued that the new MATs in Europe and other nations are spreading due to certain factors, such as increased global competition, availability of similar operating technologies, cheap and fast communication methods, increasing global homogenization of management education, rise of global consulting firms and global corporations. In addition, Sulaiman et al. [14] results in Malaysia show that change in MATs are positively and significantly associated with the organization's core competency aims and quality initiatives.

Waweru et al. [15] results indicated that change in government regulation policy largely facilitated the management accounting change in four retail companies in South Africa. However, Joshi [16] claimed that the reasons behind the slow adoption of recently developed practices in Indian companies, compared to Australian, were the conservative attitude of Indian management towards new changes. Joshi et al. [17] called for exploring whether MATs provide insight into the quality of a firm's management. They clarified that slow adoption and non-adoption of AMATs may be an indication that the firm's management does not encourage or value innovative practices. Accordingly a research issue that needs to be explored is the effect of management control system style on the management's choice of MATs.

\section{References}

1. Ittner C, Larcker D (2001) Assessing empirical research in managerial accounting: a value-based management perspective. Journal of Accounting and Economics 32: 349-410.
2. Tillema S (2005) Towards an integrated contingency framework for MAS (management accounting systems) sophistication. Case studies on the scope of accounting instruments in Dutch power and gas companies. Management Accounting Research 16: 101-129.

3. Abdel-Kader M, Luther R (2006) Management Accounting Practices in the British Food and Drinks Industry. British Food Journal 108: 336-357.

4. Green F, Amenkhienan F (1992) Accounting Innovations: a Cross-sectional Survey of Manufacturing Firms. Journal of Cost Management 6: 58-64.

5. Chenhall RH, Langfield-Smith K (1998) Adoption and Benefits of Management Accounting Practices: an Australian Study. Management Accounting Research 9: 1-20.

6. Waldron M (2005) Overcoming Barriers to Change in Management Accounting Systems. The Journal of American Academy of Business 6: 244-249.

7. Hyvonen J (2005) Adoption and Benefits of Management Accounting Systems: Evidence from Finland and Australia. Advances in International Accounting 18 97-120.

8. El-Ebaishi M, Karbhari Y, Naser K (2003) Empirical Evidence On The Use of Management Accounting Techniques In A Sample Of Saudi Manufacturing Companies. International Journal of Commerce \& Management 2: 74-101.

9. Sulaiman MN, Ahmad N, Alwi N (2004) Management Accounting Practices In Selected Asian Countries: A Review of the Literature. Managerial Auditing Journal 4: 493-508.

10. Luther R, Longden S (2001) Management Accounting in Companies Adapting to Structural Change and Volatility in Transition Economies: a South African study. Management Accounting Research 12: 299-320.

11. Wijewardena H, De Zoysa A (1999) A Comparative Analysis of Management Accounting Practices in Australia and Japan: an Empirical Investigation. The International Journal of Accounting 34: 49-70.

12. Azhar Z, Abdul Rahman IK (2008) Enhancing Management Accounting Practices in Malaysian Service Organisations: What the Present Demands of the Future? Accountants Today 12: 30-33.

13. Shields MD (1998) Management Accounting Practices in Europe : A Perspective from the States. Management Accounting Research 9: 501-513.

14. Sulaiman S, Ramli A, Mitchell F (2008) What factors drive change in management accounting in Malaysian organisations? Malaysian Accounting Review 7: 61-76.

15. Waweru N, Hoque Z, Uliana E (2004) Management Accounting Change in South Africa: Case Studies from Retail Services. Accounting, Auditing and Accountability Journal 17: 675-704.

16. Joshi PL (2001) The International Diffusion of New Management Accounting Practices: The Case of India. Journal of Accounting Auditing and Taxation 10: 85-109.

17. Joshi PL, Bremser WG, Deshmukh A, Kumar R (2011) Diffusion of Management Accounting Practices in Gulf Cooperation Council Countries. Accounting Perspectives 10: 23-53.

*Corresponding author: Mayada A Youssef, Accounting Department, College of Business and Economics, UAE University, P.O. Box 15551, Al-Ain, Abu Dhabi, UAE, E-mail: Mayada Youssef@uaeu.ac.ae

Received August 28, 2013; Accepted September 02, 2013; Published September 28, 2013

Citation: Youssef MA (2013) Management Control System Style and Management Accounting Techniques Adoption. J Account Mark 2: e121. doi: 10.4172/21689601.1000e121

Copyright: (C) 2013 Mohammed Bayoud NS. This is an open-access article distributed under the terms of the Creative Commons Attribution License, which permits unrestricted use, distribution, and reproduction in any medium, provided the original author and source are credited. 